\title{
Strategi Konflik Kognitif dalam mengatasi miskonsepsi pada peserta didik dalam mata pelajaran fisika
}

\author{
Fahmi Hujjatul Islami ${ }^{1}, \mathrm{Nana}^{2}$ \\ ${ }^{1}$ Mahasiswa Program Studi Pendidikan Fisika, Universitas Siliwangi \\ ${ }^{2}$ Dosen Program Studi Pendidikan Fisika, Universitas Siliwangi \\ Jl. Siliwangi No.24, Kahuripan, Kec. Tawang, Tasikmalaya, Jawa Barat 46115 \\ fahmihujjatulislami@gmail.com
}

\begin{abstract}
Abstrak - Kemampuan berpikir kritis merupakan kemampuan mendasar yang diperlukan dalam proses pembelajaran, termasuk dalam pembelajaran fisika. Kemampuan ini sangat dibutuhkan dalam pembelajaran agar pemahaman konsep yang diperoleh lebih mendalam. Salah satu pembelajaran yang dapat diterapkan adalah pembelajaran konflik kognitif. Konflik kognitif adalah keadaan dimana terdapat ketidak cocokan antara struktur kognitif yang dimiliki oleh seseorang dengan informasi yang baru di dapat dari luar. Ketidakyakinan, keraguan, kebingungan, kontradiksi, yang bertentangan dengan hal yang ada dalam pikirannya, maka hal tersebut menjadi tanda-tanda dari konflik kognitif. Miskonsepsi atau kosepsi merupakan sebuah kejadian dimana seseorang salah menafsirkan sebuah konsep. Miskonsepsi atau salah konsep dapat dialami oleh siapa saja, miskonsepsi juga dapat terjadi pada semua mata pelajaran terutama fisika.
\end{abstract}

Kata Kunci : Konflik Kognitif, fisika, miskonsepsi.

The ability of critical thinking is the fundamental ability required in the learning process, including in the learning of physics. This ability is indispensable in learning so that the understanding of concepts gained more in depth. One of the learning that can be applied is learning cognitive conflicts. Cognitive conflict is a condition in which there is a lack of a person's cognitive structure with new information in the outside can. Disregard, doubt, confusion, contradiction, as opposed to the thing that is in mind, then it becomes a sign of the cognitive conflict. Misconception or conception is an incident where one misinterprets a concept. Misconception or false conceptions can be experienced by anyone, misconception can also occur in all subjects especially physics.

Key Words : Cognitive Conflict, Physics, Misconception. 


\section{Pendahuluan}

Pendidikan merupakan salah satu faktor penting dalam meningkatkan kecerdasan dan kualitas hidup manusia yang sejalan dengan perkembangan ilmu pengetahuan dan teknologi, perkembangan masyarakat serta kebutuhan pembangunan. Hal ini karena tujuan pendidikan antara lain adalah mempersiapkan manusia untuk mampu hidup layak di tengah masyarakat. Proses pendidikan ini dapat ditempuh melalui pembelajaran yang terjadi di sekolah. Akan tetapi tujuan pendidikan tidak akan tercapai jika pembelajaran tidak berlangsung secara optimal.

Oleh karena itu sangat dibutuhkan pembelajaran yang tepat untuk mengakomodasi peningkatan kompetensi siswa sehingga hasil belajar siswa bisa menjadi lebih baik, khususnya kemampuan berpikir kritis siswa. Kemampuan berpikiir kritis sangat dibutuhkan dalam pembelajaran agar pemahaman konsep yang diperoleh lebih mendalam, sehingga proses belajar menjadi bermakna bagi siswa. Salah satu pembelajaran yang dapat diterapkan adalah pembelajaran konflik kognitif. Pembelajaran konflik kognitif ini dapat mengakomodasikan siswa untuk berpikir ke tahap yang lebih tinggi.

Teori konstruktivisme Piaget menyatakan bahwa ketika seseorang membangun pengetahuannya, maka untuk membentuk keseimbangan ilmu yang lebih tinggi diperlukan asimilasi, yaitu kontak atau konflik kognitif yang efektif antara konsep lama dengan kenyataan baru (Woolfolk, 1984). Rangsangan konflik kognitif dalam pembelajaran akan sangat membantu proses asimilasi menjadi lebih efektif dan bermakna dalam proses berpikir siswa. Untuk itu pembelajaran konflik kognitif perlu dilakukan dalam strategi pembelajaran fisika.

Hasil penelitian yang dilakukan Watson (2002) memberikan hasil yang jelas, bahwa pembelajaran konflik kognitif dalam pembelajaran dapat membantu siswa dalam merekonstruksi pengetahuan yang sedang dipelajari dengan pengetahuan yang telah dipelajari sebelumnya. Aktivitas belajar yang demikiran akan memberikan kebermaknaan bagi siswa melalui proses berpikir kritis yang terjadi.

Melalui artikel ini penulis akan menjelaskan bagaimana pembelajaran konflik kognitif yang ditetapkan pada pembelajaran fisika mampu meningkatkan kemampuan berpikir kritis dan mampu mengatasi miskonsepsi peserta didik, perlu diketahui terlebih dahulu mengenai, apa itu kemampuan berpikir kritis, apa itu pembelajaran konflik kognitif, serta bagaimana cara mengatasi miskonsepsi dengan menggunakan metode pembelajaran konflik kognitif.

\section{Metode penelitian}


Metode yang digunakan dalam penelitian ini merupakan penelitian studi kepustakaan (Library research). Dalam penelitian jenis ini, dikahji pengetahuanm gagasan, atau temuan yang terdapat di dalam literature sehingga memberikan informasi teoritis dan ilmiah. Data yang dikumpulkan dan dianalisis merupakan data sekunder yang berupa hasil-hasil penelitian seperti buku-buku, jurnal ilmiah, situs internet dan lainnya yang relavan dengan disposisi berpikir kritis.

Selanjutnya teknik analisis data dalan penelitian ini meliputi 3 tahapan yaitu organize yaitu mengorganisasikan literatur literatur yang digunakan. Literatur yang digunakan terlebih dahulu di tinjau agar relavan dengan permasalahan. Pada tahapan ini penulis melakukan pencarian ide, tujuan, dan simpulan dari beberapa literatur dimulai dari membaca abstrak, pendahuluan metode dan pembahasan, serta melakukan pengelompokkan literature berdasarkan kategorikategori tertentu, kedua, yaitu menyatukan hasil organisasi literature menjadi suatu ringkasan agar menjadi satu kesatuan yang padu, dengan mencari keterkaitan antar literatire, ketiga, identify yaitu mengidentifikasi isu-isu kontroversi dalam literatur. Isu kontroversi yang dimaksud adalah isu yang dianggap sangat penting untuk dianalisis, untuk mendapatkan suatu karya tulis yang menarik untuk dibaca.

\section{Hasil dan Pembahasan}

Menurut Depdiknas (2008) dalam (Dyahsih, 2018) konflik adalah percekcokan, perselisihan dan pertentangan yang disebabkan adanya dua gagasan atau lebih atau keinginan yang saling bertentangan untuk menguasai diri sehingga mempengaruhi tingkah laku. Sedangkan kognitif adalah berhubungan dengan atau melibatkan kognisi yang berdasarkan kepada pengetahuan faktual yang empiris.

Konflik kognitif muncul dari hasil penelitian Piaget sekitar tahun 1970an. Menurut Michael (Ismaimuza, 2010) dalam (Dyahsih, 2018) konflik kognitif adalah suatu situasi dimana kesadaran individu mengalami keseimbangan. Carsten, K. W., De Dreu, \& Van De Viert E (1997) dalam (Dyahsih, 2018) menjelaskan bahwa konflik kognitif adalah orientasi tugas yang muncul dari perbedaan keputusan atau pendapat. Konflik kognitif adalah bagian terpenting dari proses mengidentifikasi, memperoleh dan mengkombinasikan keahlian, kemampuan dan perspektif untuk menghasilkan keputusan yang berkualitas tinggi. Menurut Piaget (Suyono \& Hariyanto, 2011) dalam (Dyahsih, 2018) adanya informasi baru yang diperoleh 
dari lingkungan kemudian dicocokkan dengan skema pembelajaran, hal ini menyebabkan disekuilibrium (ketidakseimbangan) pada struktur kognitif yang disebut konflik kognitif. Ketidakseimbangan tersebut didasari adanya kesadaran akan informasi-informasi yang bertentangan dengan informasi yang dimiliki yang telah tersimpan dalam struktur kognitif seseorang (Dahlan, dkk, 2012) dalam (Dyahsih, 2018).

(Nana, 2018) Miskonsepsi telah terjadi apabila pemahaman siswa terhadap suatu konsep berbeda dengan apa yang dimaksud oleh masyarakat ilmiah atau siswa memberikan pemahaman yang berbeda terhadap suatu konsep dengan apa yang dimaksud oleh kurikulum atau buku-buku acuan yang menjadi pegangan. Miskonsepsi yang terjadi pada siswa antara lain disebabkan oleh pemberian konsep-konsep atau faktafakta yang terlepaslepas oleh guru, sehingga siswa didalam menerima konsep tidak utuh atau mengalami kebingungan. Penggunaan metode mengajar oleh guru yang tidak sesuai dengan tujuan materi yang akan diajarkan menyebabkan siswa menerima konsep lain dari yang dimaksud. Miskonsepsi juga dapat terjadi dari bukubuku acuan yang digunakan buku-buku itu menyajikan konsep-konsep yang tidak lengkap atau menggunakan konsep lain yang mungkin para siswa tidak kenal untuk menjelaskan atau mendefinisikan konsep tersebut. Umumnya buku-buku hanya memuat generalisaigeneralisasi tanpa memperhatikan perkecualianperkecualian sehingga guru itu sendiri mengalami keraguan dalam menjelaskan mana yang pasti mana yang tidak.

Banyaknya faktor pencetus miskonsepsi seperti yang telah dipaparkan diatas, miskonsepsi besar kemungkinan terjadi pada pelajaran ilmu Fisika di SMP. Ilmu Fisika yang sebagian besar bersifat abstrak dan memerlukan penalaran yang cukup tinggi, sehingga di dalam mempelajarinya menyulitkan siswa dalam menggambarkan kedalam bentuk yang sebenarnya, dalam memahami konsepkonsepnya serta dapat menjadi verbalisme, hafal kata-katanya tetapi tidak mengerti arti sebenarnya. Ketidakmampuan tersebut menimbulkan miskonsepsi bagi siswa dalam mempelajari konsep-konsep Fisika.

Menurut hasil penelitian pendekatan konflik kognitif untuk remidiasi miskonsepsi pembelajaran suhu dan kalor dalam (Nana, 2018) bahwa siswa yang dapat menjawab dengan benar sebelum remidiasi rata-rata kelas $8 \mathrm{~A}$ 29,6\% kelas 8B 32,9\% dan yang menjawab salah sebelum remidiasi sebesar kelas $8 \mathrm{~A}$ $70,4 \%$ kelas 8B $67,1 \%$. Sedangkan setelah remidiasi 
siswa yang dapat menjawab dengan benar meningkat ratarata kelas $8 \mathrm{~A} 55,5 \%$ kelas $8 \mathrm{~B}$ $59,1 \%$ dan yang menjawab salah kelas $8 \mathrm{~A}$ hanya $44,5 \%$ dan kelas 8B 40,9\%.

Demikian juga pada saat tes 2 sesudah remidiasi siswa yang dapat menjawab dengan benar yaitu kelas $8 \mathrm{~A} 81,2 \%$ kelas $8 \mathrm{~B}$ $83,7 \%$. Sedangkan pada tes 3 setelah remidiasi pada kelas $8 \mathrm{~A}$ $92,6 \%$ sedangkan kelas $8 \mathrm{~B}$ 92,3\%. Sedangkan yang menjawab salah pada tes 2 kelas 8A 18,8\% kelas 8B $16,3 \%$, pada tes 3 yang menjawab salah kelas $8 \mathrm{~A} 7,4 \%$ kelas 8B 7,7\%.

\section{Kesimpulan}

Kemampuan berpikir kritis merupakan kemampuan mendasar yang diperlukan dalam proses pembelajaran, termasuk dalam pembelajaran matematika. Kemampuan ini sangat dibutuhkan dalam pembelajaran agar pemahaman konsep yang diperoleh lebih mendalam, sehingga proses belajar menjadi bermakna bagi siswa.

\section{Daftar Pustaka}

Carsten, K. W., De Dreu, \& Van De Vliert, E. 1997. Using conflict in organizations. London: SAGE.

Pembelajaran Konflik Kognitif .... Dyahsih Alin Sholihah dan Widha Nur Shanti

Depdiknas. 2008. Kamus besar bahasa Indosesia (edisi
4). Jakarta: PT Gramedia Pustaka Utama.

Dyahsih @all. 2018. Pembelajaran Kognitif Untuk Meningkatkan Kemampuan Berpikir Kritis Matematis Siswa.

Ismaimuza, 2010. Pengaruh pembelajaran berbasis masalah dengan strategi konflik kognitif terhadap kemampuan berpikir kritis dan sikap siswa SMP. Jurnal Pendidikan Matematika, 4 (1), 1-10.

Nana. 2018. Penggunaan Pendekatan Konflik Kognitif Untuk Remidiasi Miskonsepsi Pembelajaran Suhu dan Kalor.

Suyono \& Hariyanto. 2011. Belajar dan pembelajaran:Teori dan konsep dasar. Bandung: PT Remaja Rosdakarya. 